This is an Open Access article, distributed under the terms of the Creative Commons AttributionNonCommercial-ShareAlike licence (http://creativecommons.org/licenses/by-nc-sa/4.0/), which permits non-commercial re-use, distribution, and reproduction in any medium, provided the same Creative Commons licence is included and the original work is properly cited. The written permission of Cambridge University Press must be obtained for commercial re-use.

\title{
No Country for Men: Searching for Late Medieval Submerged Settlements in the North-Eastern Zuiderzee Area in the Netherlands
}

\author{
Yftinus T. van Popta (1) \\ Institute of Archaeology, University of Groningen, The Netherlands
}

This article focuses on the maritime cultural landscape of the former Zuiderzee (AD 1170-1932) in the central part of the Netherlands. Since the large-scale reclamations from the sea (1932-1968), many remains have been discovered, revealing a submerged and eroded late medieval maritime culture, represented by lost islands, drowned settlements, cultivated lands, shipwrecks, and consequently socio-economic networks. Especially the north-eastern part of the region, known today as the Noordoostpolder, is testimony to the dynamic battles of the Dutch against the water. By examining physical and immaterial datasets from the region, it is possible to give a modern-day idea of this late medieval maritime cultural landscape. Spatial distribution and densities of late medieval archaeological remains are analysed and compared to historical data and remote sensing results. This interdisciplinary approach has led to the discovery of the remains of the drowned settlement of Fenehuysen.

Keywords: submerged settlements, late Middle Ages, Zuiderzee, maritime cultural landscape, Fenehuysen, The Netherlands

\section{INTRODUCTION}

Up to the early twentieth century, the central part of the Netherlands was dominated by the hazardous Zuiderzee (Southern Sea), a large inlet of the North Sea that reached as far inland as Amsterdam. It served the Dutch, among others, as a transport zone, fishing ground and battlefield (Figure 1). For centuries, the inhabitants of this maritime region were plagued by rapid floods, storm surges and consequential land loss (Van den Biggelaar et al., 2014; Vos, 2015; Van Popta et al., in prep.). The Zuiderzee also brought much prosperity to the Netherlands, as a traffic junction connecting different regions (transport landscape) and as a fishing ground supplying food and surplus (resource landscape; Westerdahl, 2013; Van Holk, 2017; Van Popta et al., 2019). At the beginning of the twentieth century, the Dutch State decided to build a large dam (Afsluitdijk) that would close off the Zuiderzee from the North Sea and Wadden Sea. The construction was completed in 1932, and soon after parts of the former Zuiderzee were reclaimed, cultivated, and populated. This led to the creation of four major polders: 

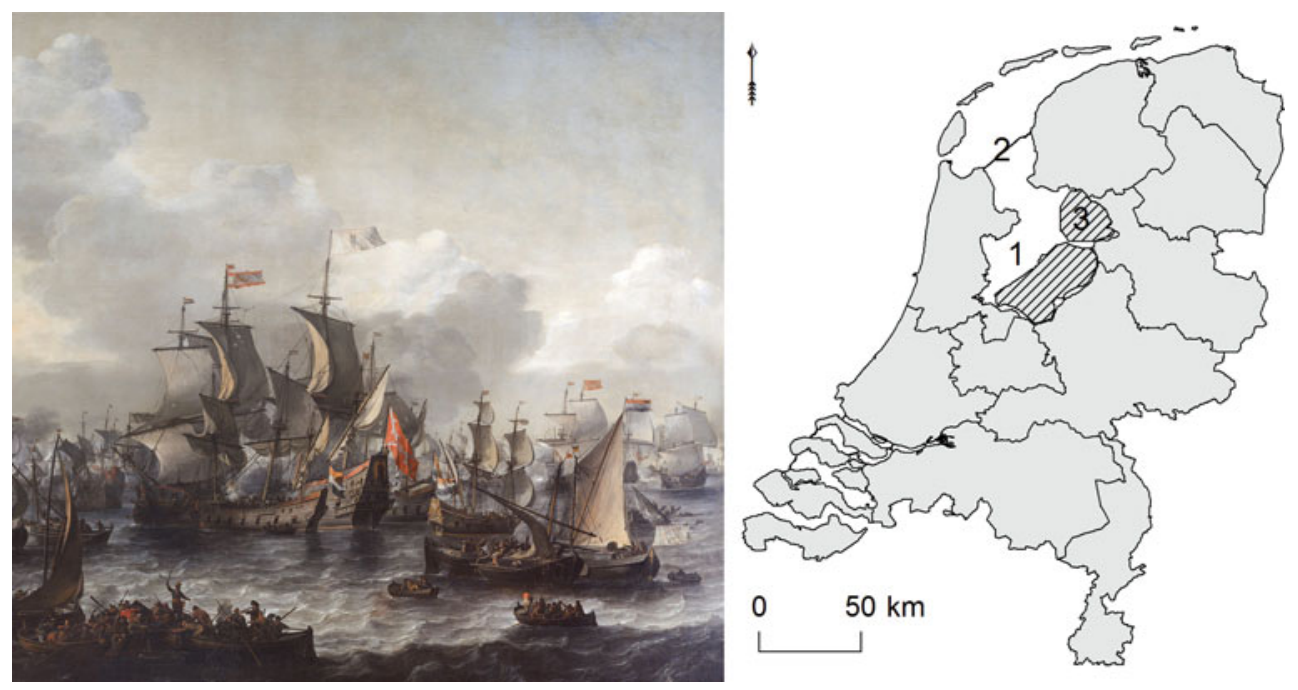

Figure 1. Left: an impression of the Zuiderzee during the Battle on the Zuiderzee between the Dutch and Spanish fleet (Jan Theunisz, Blanckerhoff, 1663, Rijksmuseum Amsterdam). Right: the former Zuiderzee in the central part of the Netherlands (1), separated today from the North Sea by a large dam (2). The research presented in this article focuses on the Noordoostpolder region (3), which is part of the reclaimed province of Flevoland (hatched lines).

Image of the Battle of the Zuiderzee reproduced by permission of the Rijksmuseum (available at https://www.rijksmuseum.nl/en/collection/SK-A-3235).

Wieringermeerpolder, Noordoostpolder, Eastern Flevoland, and Southern Flevoland, of which the latter three constitute the province of Flevoland. The reclamations dramatically changed the nature and focus of the region, from maritime to terrestrial and from fishing to agriculture (Figure 2). The north-eastern part of the former Zuiderzee, now known as the Noordoostpolder and the study area presented here, clearly illustrates these changes: the islands and coastal settlements became part of the mainland, leading to a substantial loss of the region's maritime identity (Geurts, 2005: 263, 283).

A close examination of the present-day landscape of the Noordoostpolder shows that it is still possible to gain insights into the maritime past of the region. For example, the former island of Schokland in the southern part of the region is now completely surrounded by land, being an island on dry ground. Schokland was the home of the Schokker community for many centuries, and in its heyday the island was inhabited by more than 600 people who lived on three large artificial mounds (Geurts, 2005; Van Hezel \& Pol, 2008; Van Popta \& Aalbersberg, 2016). The island suffered from many floods that reduced its size and number of inhabitants. For centuries, the Dutch government spent much money on the island to maintain the coastal defences and support its inhabitants. In the second half of the nineteenth century, it was decided to evacuate the island as the inhabitants were no longer able to support themselves (Van Hezel \& Pol, 2008: 201). Today, the island is uninhabited, and only the lighthouse, church, an old quay, and several small fisherman's cottages remind visitors of the once densely populated mounds.

The example of Schokland is one of the most obvious examples of 'experiencing the maritime past' of the north-eastern Zuiderzee region. Other appropriate 


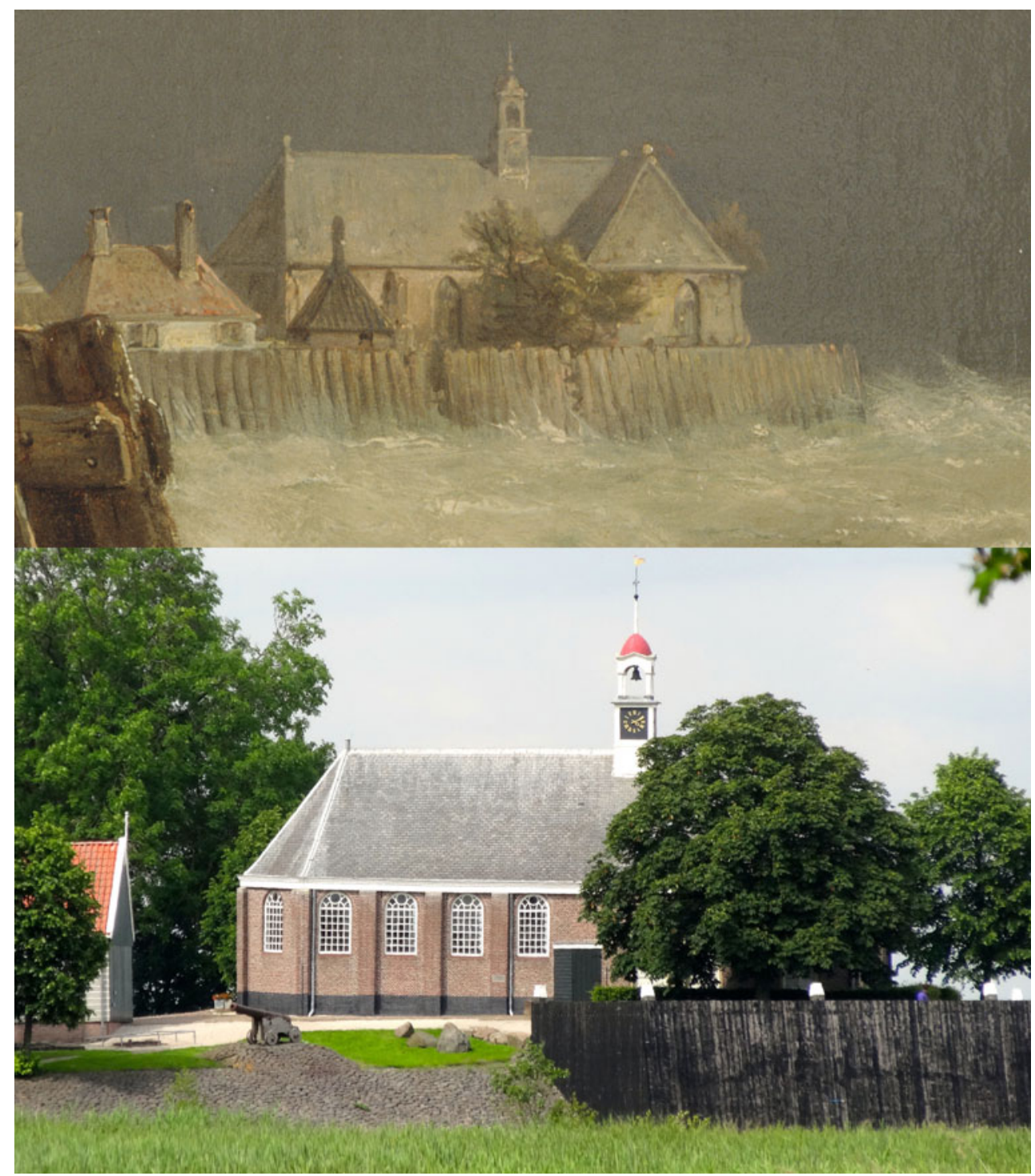

Figure 2. The church of Ens on the island Schokland surrounded by the Zuiderzee in 1850 (painting by Hermanus Koekkoek, Zuiderzeemuseum) and photographed as it appears today.

Painting of the church at Ens reproduced by permission of the Zuiderzeemuseum (available at https://www.zuiderzeecollectie.n1/object/collect/Zuiderzee_museum-4755).

locations in the region are the past maritime cultural centres (see Westerdahl, 2013: 738), Urk island and seaports such as Kuinre, Vollenhove, or Blokzijl along the former eastern shore of the Zuiderzee. These past 'maritime cultural centres' are the 'tip of the iceberg', being easily accessible physical evidence of maritime culture. The lower and larger part of the 'iceberg' consists of evidence including pottery scatters, field boundaries, or remains of dikes, and of historical maps and charters, place names, folklore, and oral history. The analysis of these datasets 
forms the core of the author's doctoral research, which aims to gain a new and more accurate idea of the late medieval maritime cultural landscape of the Zuiderzee region. The objective of the present article, which stems from this project, is to recognize and characterize the submerged and eroded cultural remains, their locations, and their visibility in other sources. The discovery of remains of the drowned late medieval settlement of Fenehuysen (Fene =veen = peat, and buysen $=$ buizen $=$ houses $)$ constitutes the main result.

\section{Research Area: From the Zuiderzee TO THE NOORDOOSTPOLDER}

The Noordoostpolder comprises the north-eastern part of the Zuiderzee region: a large tidal lagoon of the North Sea surrounded by inhabited peatlands. In Roman times, the region was described by Pomponius Mela (Chorographia III, 24) as an area of peatlands with multiple lakes: Lacus Flevo. During this period, no marine influence affected the region. In the early Middle Ages, the name of the region changed to Almere (all lakes), referring to even larger bodies of fresh water in the region (see Vos, 2015; Van Zijverden, 2017). Human interference in the natural landscape, in the form of cultivation and peat reclamation causing subsidence through oxidation and erosion of the peat, is considered the main reason for the landscape changes (Vos, 2015: 67). Massive floods in the twelfth and thirteenth century $\mathrm{AD}$ eventually breached the peat barrier that separated the Almere from the North Sea, resulting in the Zuiderzee (Figure 3; Pierik et al., 2016: 10; Van Popta et al., in prep.). As a consequence, the North Sea reached the coastal plain and started eroding peatland more often and over more widespread areas than before (Van den Biggelaar et al., 2014; Vos, 2015; Pierik et al., 2016; Van Popta et al., in prep.).

Even though it is commonly accepted that the Zuiderzee existed between approximately $\mathrm{AD} 1170$ (the year of the catastrophic All Saints' Flood) and 1932 (building of the Afsluitdijk), its dynamics changed over time. Parts of the peatlands that were mentioned by Mela in the first century $\mathrm{AD}$ still existed in the Middle Ages. The largest surfaces could be found in the north-eastern Zuiderzee region (Van Popta, 2016). Recent research has shown that large parts of these peatlands were cultivated in the Middle Ages, but that people were driven inland by the water (Van Popta et al., in prep.). Habitation was certainly possible on the known island of Urk (a Saalian boulder clay outcrop), but probably also in other parts of the research area (Figure 4). Heavy storm surges in the thirteenth and fourteenth centuries eventually flooded and buried most of the medieval peatlands, leaving only small parts of Urk and Schokland exposed. The size of the Zuiderzee remained more or less stable from the seventeenth century onwards (also because of the many dikes that were constructed along the shore) until the construction of the Afsluitdijk in 1932. Largescale reclamations then transformed the eastern part of the sea into land, and thus the province of Flevoland was created.

\section{Approach}

\section{The maritime cultural landscape}

The analysis of submerged late medieval settlements in the Noordoostpolder region fits the concept of the maritime cultural landscape, as introduced by Scandinavian maritime archaeologist Christer Westerdahl in the late 1980s and early 1990s 


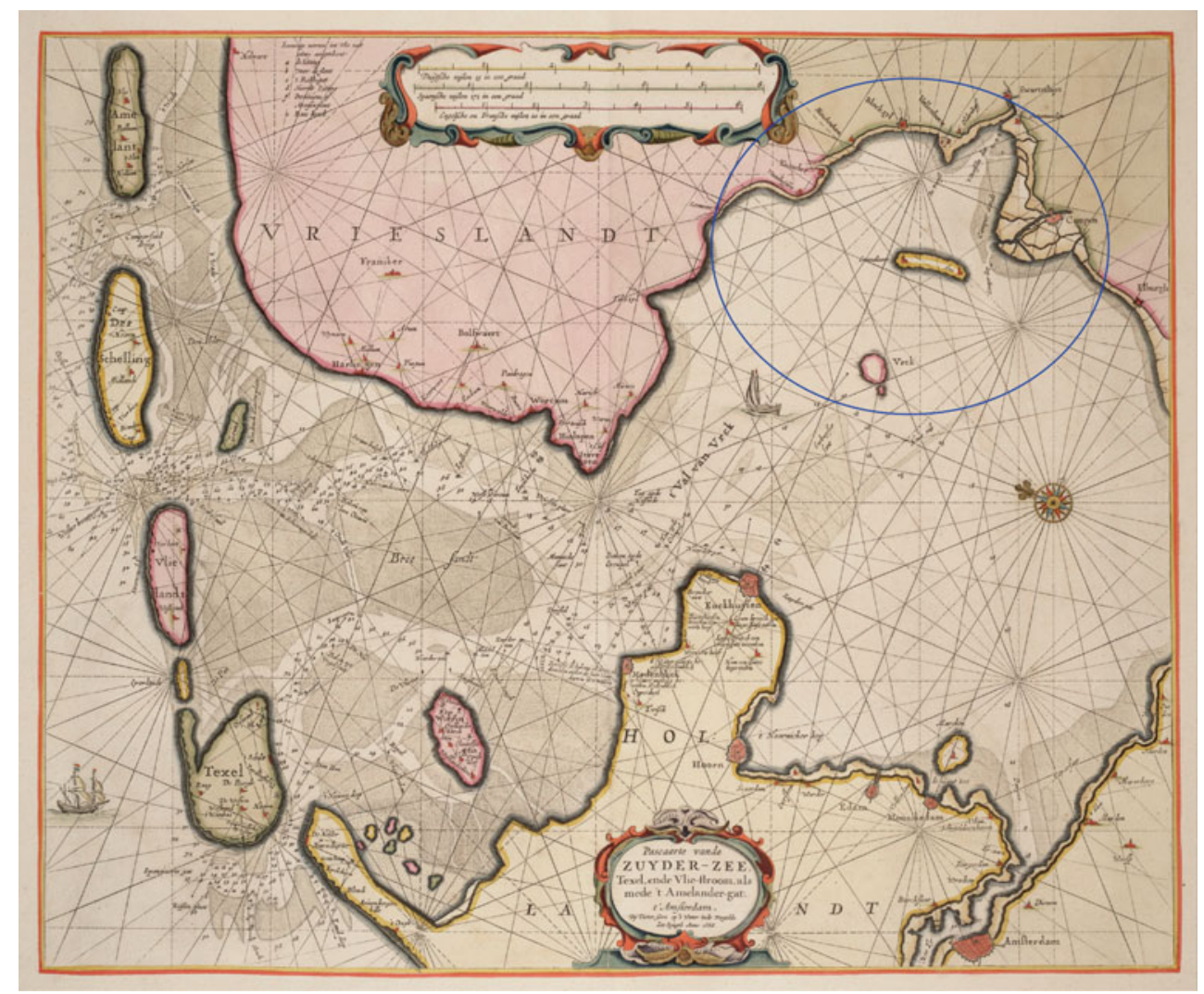

Figure 3. Map of the Zuiderzee region, c. 1666. by Pieter Goos (Geheugen van Nederland). The circle marks the study area (Noordoostpolder region).

Map reproduced by permission of Geheugen van Nederland / Koninklijke Bibliotheek (available at https://www.geheugenvannederland.nl/en/geheugen/view/zeekaart-zuiderzee-westelijke-waddenzee-goos-pieter? coll=ngvn\&maxperpage $=36 \&$ page $=1 \&$ query $=$ Goos\&identifier $=$ NESA01\% 3AL17-0050).

(Westerdahl, 1992, 2013; Duncan, 2006). It was conceptualized to bridge the boundaries between the terrestrial and maritime counterparts and relate maritime culture to both. At first, the concept focused only on the physical aspects of maritime culture like shipwrecks, harbours and related structures (Westerdahl, 1978). Soon, it was realized that the maritime cultural landscape should be treated as a more holistic concept, also including immaterial and cognitive data under the following definition: "The whole network of sailing routes, with ports, havens and harbours along the coast, and its related constructions and other remains of human activity, underwater as well as terrestrial' (Westerdahl, 1992: 6; 2008: 212; 2011: 339; 2013: 744-45).

The notion of a maritime cultural landscape had a deep impact on maritime archaeology worldwide, as attested by numerous studies that followed in its footsteps. However, as Duncan (2006) demonstrates, many studies claim to study the maritime cultural landscape while in fact they only address part of it (in many cases the physical remains), making them archaeological landscape studies rather than maritime cultural landscape studies. 


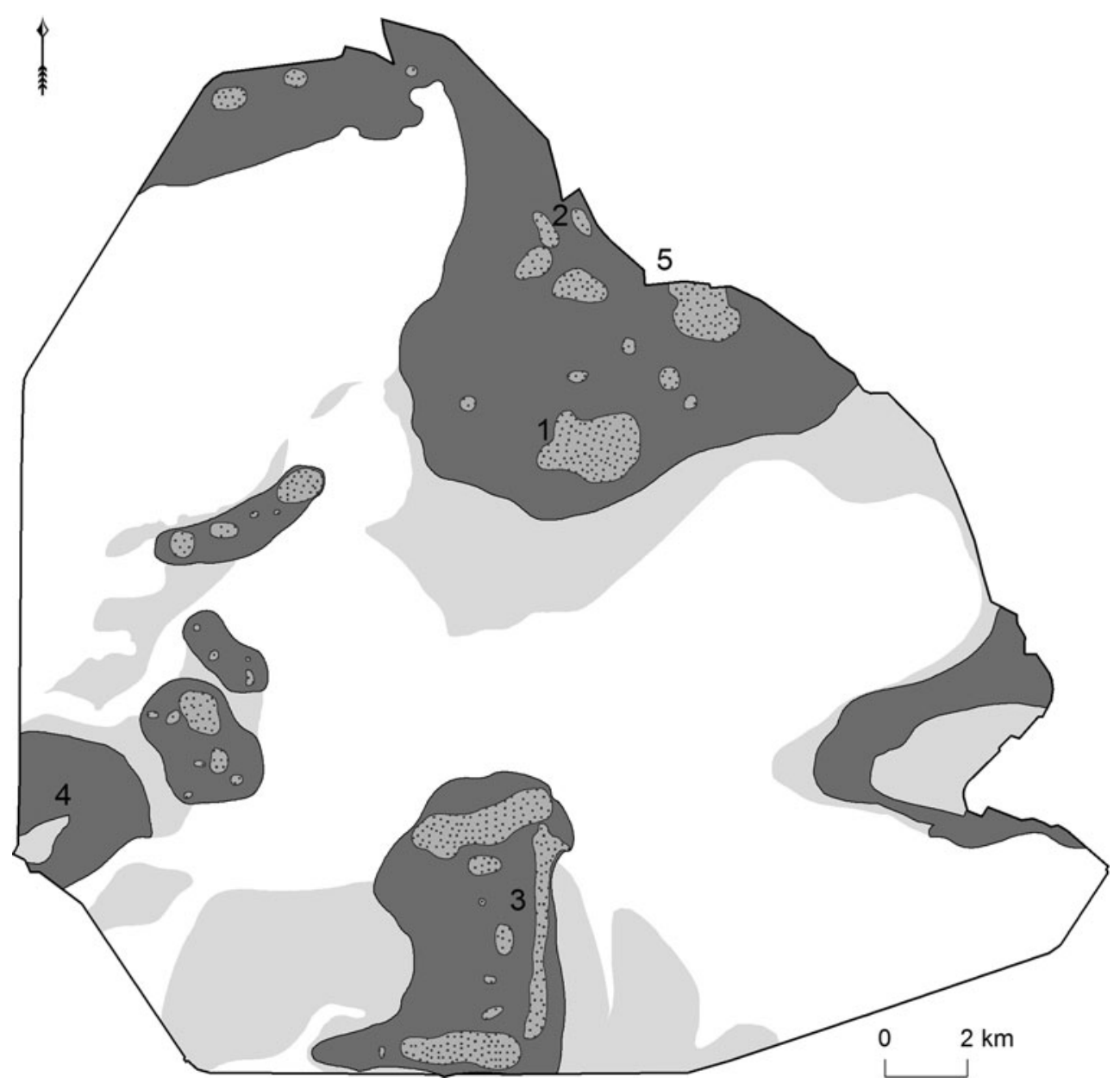

Figure 4. Reconstruction of the north-eastern Zuiderzee region in medieval times (ad 1100). In grey: land (dark is settlement, light is submerged); white represents water. 1: Fenehuysen I; 2: Fenehuysen II; 3: Schokland; 4: Urk, 5: Kuinre.

Furthermore, it is important to keep in mind that the datasets used are analysed from a modern point of view. Past perceptions may differ: landscapes are multivalent, and perceptions depend on perspective and personal and communal experience (Ingold, 1993; Westerdahl, 2004; Duncan, 2006).

\section{Materials}

In this article, datasets from several disciplines (archaeology, (landscape) history, geography, geology) are combined to retrieve the locations of late medieval submerged settlements. The most important dataset is the Medieval Settlement Database of the Noordoostpolder (MSD): it contains an overview of all late medieval archaeological objects found in the research area, primarily thousands of pottery sherds, bricks, roof tiles, and animal bones. The data are compiled from the Dutch National Archaeological Database (Archis), the archaeological repository of the province of Flevoland, 
archaeological distribution maps, and relevant archaeological literature such as the archaeological series 'Quarterly updates on the Zuiderzee constructions' (Ministerie van Verkeer en Waterstaat, 1920-1976). The latter source provides an overview of the earliest archaeological finds in the region encountered during the reclamation works. The precise number of late medieval archaeological objects in the entire region is unknown, as some primary sources do not mention exact numbers. The distribution map made by the archaeologist Van der Heide, drawn in the 1950s, and the oldest distribution map of the region, illustrate late medieval highdensity areas, but lack quantities of objects. Furthermore, only part of the Archis database contains exact numbers of archaeological finds; in many cases, no quantitative information is given. It is known that many archaeological sites contain hundreds of late medieval objects and that several archaeological sites contain over 2000 objects (lots NP 14 and NP 23, based on records in repository of the province of Flevoland). It is expected that many other archaeological finds have never been recorded because (1) they were found by land owners who simply threw them away, (2) they were considered 'archaeological noise', or (3) they were found in the early days of archaeological research in the Noordoostpolder when a recording system had not yet been developed. In addition, hundreds of archaeological objects are found yearly by amateur archaeologists who search the arable fields after ploughing, indicating that similar late medieval remains are still present in the soil. To summarize, tens of thousands of late medieval objects have been discovered in the Noordoostpolder and there are many more objects preserved in situ.

Several historical charters were also used, including a copy of a thirteenth-century charter of the St Odulphus monastery near
Stavoren (province of Frisia). This charter describes the possessions of the monastery (chapels and goods) in a region that encompasses the area of study (Mol \& Van Vliet, 1998; Mol, 2011). Several sixteenth- and seventeenth-century historical maps (e.g. one of the oldest and quite accurate map of the entire Zuiderzee region made by Christiaan Sgroten in 1573) provided further evidence about the final stages of land erosion and settlement within the research area (Figures 3 and 4). One should, however, keep in mind that these maps depict the research area after the submergence of many late medieval settlements. Finally, modern remote sensing datasets including (historical) aerial photographs, Digital Elevation Models, and satellite images were analysed for archaeological traces such as historic dikes, ditches and mounds.

\section{Method: locating and characterizing submerged settlements}

The tens of thousands of late medieval objects in the MSD indicating human presence in the Noordoostpolder region have been misinterpreted in the past as noise or as ships' waste. This means that late medieval settlement areas remain unrecognized, lack a protected status (except Schokland and Urk) and are therefore subject to severe anthropogenic disturbance (ploughing). To prevent further damage to these sites and to pinpoint their locations, the current project determined that several criteria must be met. If an archaeological findspot meets these criteria, it can be labelled a late medieval 'settlement area'. First, a possible settlement site has to contain multiple objects. All isolated, single objects found in the study area are disregarded: they cannot be interpreted as settlement remains because the once inhabited lands have been highly 
disturbed by marine erosion, making it likely that small archaeological objects were transported and redeposited. Second, the number of archaeological objects from a potential settlement site has to be significantly higher (factor 10) than the number of objects in the surrounding area. In other words, the site must be visible as a high-density area on an archaeological distribution map. Third, the composition of the archaeological objects representing a submerged settlement should be diverse and not limited to just pottery. There should be a combination of sherds, animal bones, and preferably bricks and/or roof tiles. Especially the presence of bricks and roof tiles should be considered a strong indicator of former buildings. It is assumed that regular late medieval houses in the research area were made of wood, and that important buildings such as a church or chapel were constructed from stone (bricks or tufa). It is therefore expected that the quantity of bricks and roof tiles on medieval archaeological sites is relatively low.

This three-step-methodology led to the creation of a map that indicates the presence of all archaeologically recorded late medieval settlement areas (see below). The settlement areas on this map were compared to historical sources (such as charters and maps) that provide information on their existence and location. Furthermore, remote sensing techniques were applied to possible site locations to document physical remains, and finally an archaeological excavation was conducted at one settlement location with clear archaeological and historical traces.

\section{Results: Submerged Settlements}

In order to identify the location of late medieval submerged settlements, all late medieval archaeological findspots in the
Noordoostpolder with a minimum number of six objects were selected from the MSD. The density of the archaeological records and objects from the MSD was then analysed in ArcGIS, using Kernel Density and Point Density to highlight areas with a high findspot density (Figure 5). Most of the archaeological findspots contain at least some late medieval pottery, typically late medieval wares like Globular pottery, Pingsdorf ware, Paffrath pottery, Andenne ware and Proto-stoneware (Bartels, 2011). The majority of these sherds date to between the twelfth and fourteenth century, which implies that the settlements were built from $\mathrm{AD} 1100$ onwards and were abandoned in the fourteenth century (though a more thorough study of these dates would be desirable). As said, it is the combination of materials that provides the strongest indication of the presence of a late medieval settlement. Therefore, an overview was made of the sites that contain at least two object categories, removing all sites that contain only one object category (Figure 6).

There are seven main settlement areas that meet the criteria of a high-density area with a varied composition of archaeological material (see Figure 6). Three of these areas are well-known: they are the islands of Urk (1) and Schokland (2), and the former coastal town of Kuinre (3). Four settlement areas in the research area represent unknown settlements. Two of them (4 and 5) are located in the direct vicinity of Kuinre, while the other two are to the north of Urk and Schokland. A copy of the thirteenth-century St Odulphus monastery charter is of great importance, as it mentions the names of almost 30 chapels and goods (settlements) in a clear geographical order (Figure 7). Many of these names refer to still existing settlements, except for Nagele, Marcnesse and Fenehuysen, which should be located within the study area according 


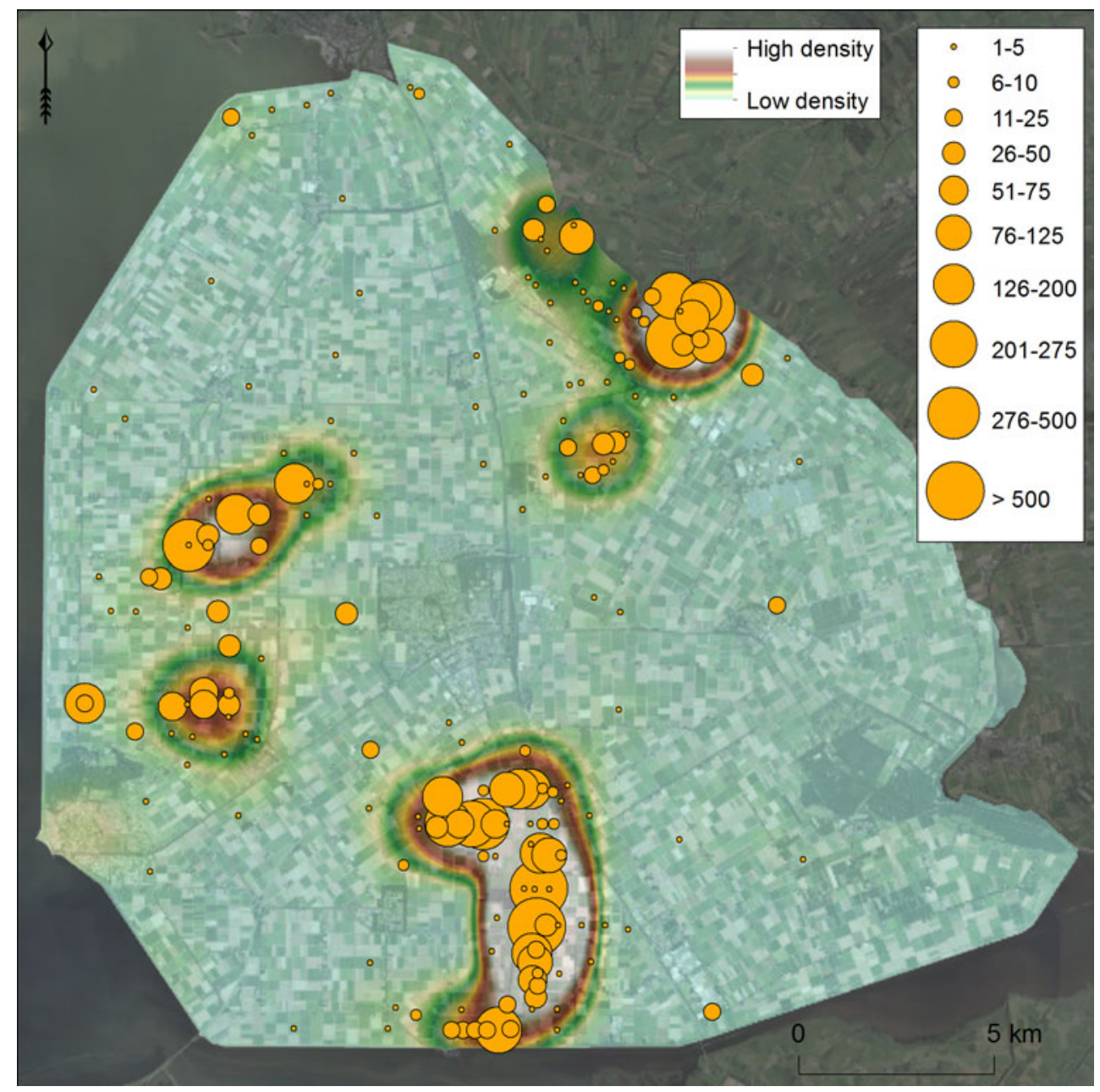

Figure 5. Combined archaeological density and distribution map, based on the content of the MSD database.

to the geographical order. The charter does not mention the exact location of these settlements, hence the oldest historical maps of the study area needed to be checked. The name Fenehuysen, meaning 'houses on peat', appears on multiple historical maps of the Zuiderzee region (the oldest dates to 1573). The settlement is shown in these maps along the coast of the Zuiderzee, to the north-west of Kuinre. This location matches the archaeological data and corresponds to archaeological settlement area 5. Interestingly, a seventeenth-century map mentions the name Veenhuijsen (a corruption of Fenehuysen) twice: one location corresponds to settlement area 5 along the coast, the second is written on the waters south of Kuinre. Above this name, there is a small icon of a building (probably a church) sticking out of the water. The information from this map is of great importance as it not only depicts a submerged settlement, but also shows that Fenehuysen has shifted inland due to rewetting and erosion of the peatlands (De Bont, 2008). The location of submerged Fenehuysen corresponds directly with the archaeological settlement area 4 . The names 


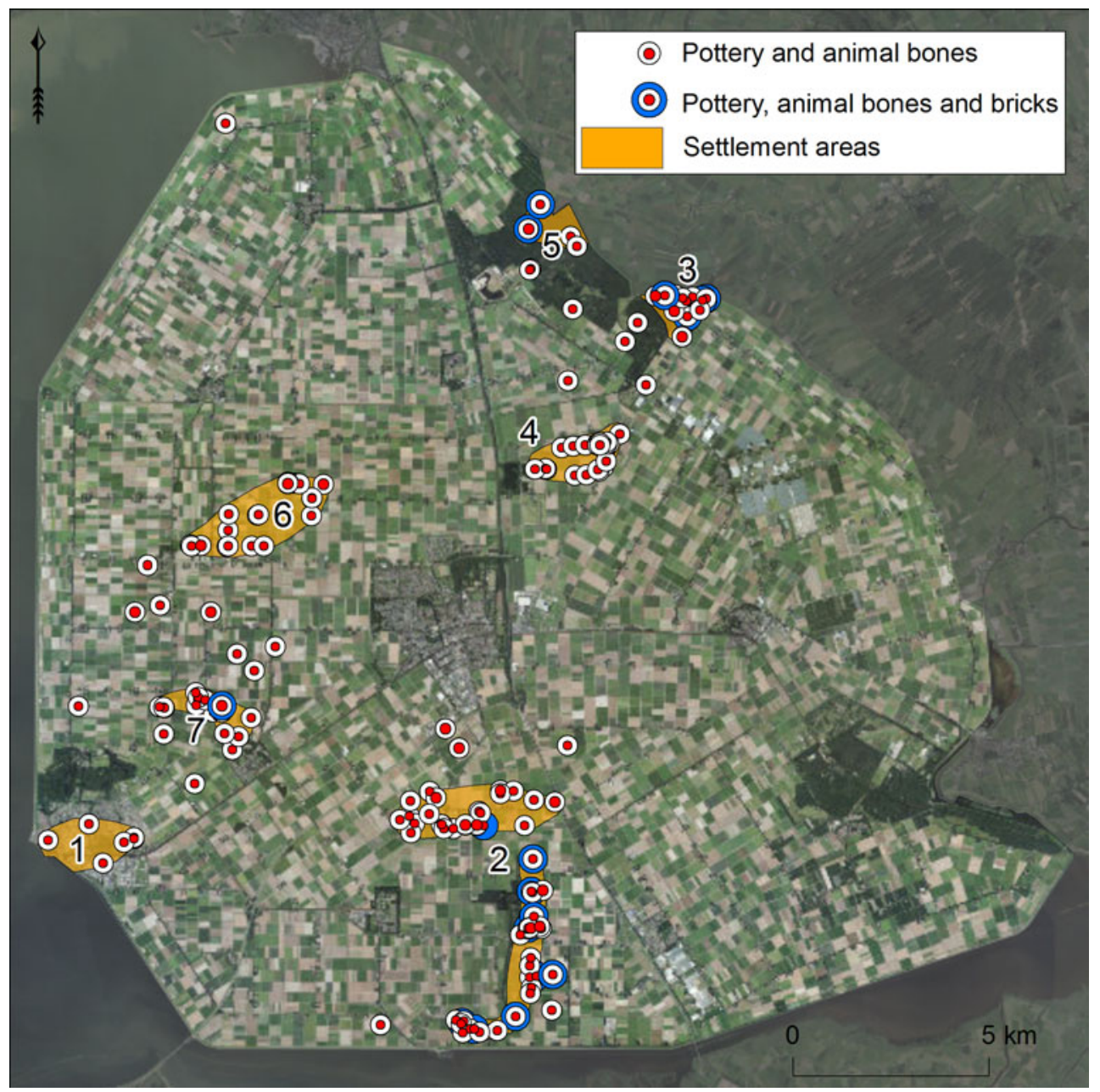

Figure 6. Distribution map of archaeological finds, only showing sites that contain at least two object categories.

Nagele and Marcnesse are not mentioned on any of the historical maps, but it is possible that they belong to settlement areas north of Urk and Schokland (areas 6 and 7).

Further examination of the four unknown settlement areas through the analysis of remote sensing datasets (aerial photographs, satellite images, and LiDAR data) did not reveal new evidence for three locations (4, 6, and 7). Extensive ploughing has levelled the former seabed and thoroughly disturbed the archaeological remains, leaving only dense scatters of archaeological objects on the surface in these areas.
However, the fifth settlement-area, that of Fenehuysen, had been turned into forest directly after the reclamations, leaving the former seabed largely intact. Therefore, this settlement area was considered most suitable for further in-depth research.

\section{Finding Fenehuysen: physical and immaterial evidence}

The first evidence for the existence and location of the drowned settlement of Fenehuysen came from the late medieval 


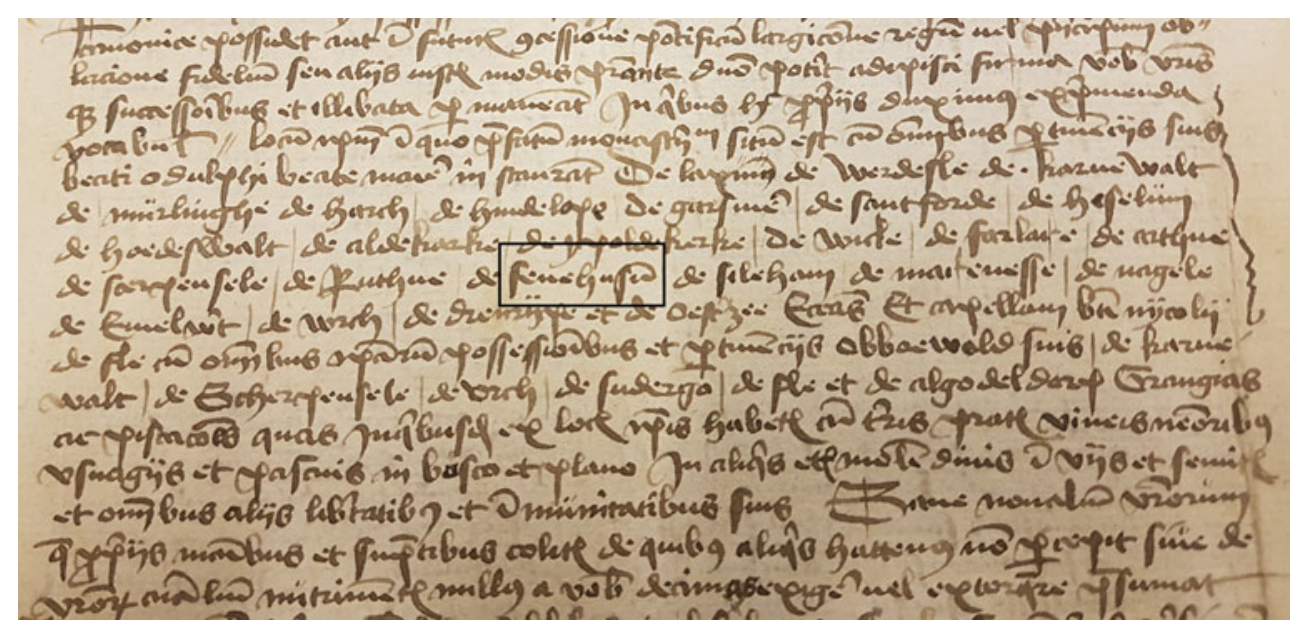

Figure 7. Fifteenth-century copy of a thirteenth century charter of the St Odulphus monastery that mentions Fenehuysen (outlined in rectangle).

charter of the St Odulphus monastery. The list of names in the charter has a geographical order, suggesting that the settlement was located somewhere between the eastern shore of the Zuiderzee and Urk island. The spatial distribution of the objects from the MSD helped pinpoint settlement locations in the study area. Further evidence came from the sixteenthcentury maps of the Zuiderzee region, which show two locations for Fenehuysen. The locations on the historical maps correspond closely with settlement areas 4 and 5. Settlement area 4 is interpreted as the first location of Fenehuysen, lying on the south-eastern tip of a large peatland peninsula in the north-eastern part of the research area. Based on pottery finds, it is estimated that the settlement was submerged before AD 1400 and that its inhabitants moved further inland. Due to intensive marine erosion, modern ploughing, and peat compaction, no in situ physical evidence is expected on the present-day location of the site. Nevertheless, this settlement area is interpreted as the origin of Fenehuysen and therefore called Fenehuysen I.

The second location of the settlement (area 5), now referred to as Fenehuysen II, is more promising as it is depicted on several sixteenth-century maps near the north-eastern shore of the Zuiderzee in an area that is nowadays covered by the Kuinder forest. No clear concentrations of late medieval archaeological objects were found in the forest, but this could also be the result of limited soil disturbance since the reclamations. Other datasets were consulted for evidence of medieval habitation and land cultivation. The first category of evidence came from the analysis of aerial photographs. The oldest consulted were made by the Royal Air Force (RAF) during the Second World War; they show the settlement area after the reclamations but before forestation. Some northwestsoutheast oriented linear discolorations are visible on these photographs, stretching along a part of the eastern shore of the Zuiderzee that includes settlement area 5. More recent aerial photographs did not add to this, as they only depict the treetops of the forest. But more advanced remote sensing methods allow us to create Digital Elevation Models (DEMs) of the forest soil by using LiDAR (Airborne Light Detection and Ranging; Davis, 2008). Detailed LiDAR footage of the 
Kuinder forest soil not only confirmed the presence of the linear structures that were spotted on the aerial photographs of the RAF but also revealed far more of these structures on the forest soil, which modern aerial photographs and satellite images could not detect. Further analysis of the LiDAR data revealed that one particular area of the forest, corresponding to the historical site of Fenehuysen II, contains a dense network of linear and rectangular structures with a slightly higher elevation than the surroundings (a difference of $c$. $30-50 \mathrm{~cm}$ in height). These traces had not been noticed before and were therefore of interest for further archaeological research (Figure 8). What exactly do they represent, and would an archaeological excavation reveal the remains of Fenehuysen II?

\section{Archaeological excavation}

In May and June 2017, archaeological investigations by the University of Groningen were conducted in the area with dense linear structures in the Kuinder forest. The excavation consisted of eight test trenches, varying in length from 2 to $8 \mathrm{~m}$, dug through a selection of linear structures. The purpose was to analyse and document their sections. In addition, over 30 cores were taken throughout the excavation area to obtain information on the natural stratigraphy and to compare the natural stratigraphy with sections of the linear structures. GPS and a Total Station were used for locating the linear structures, although many could be spotted with the naked eye. All trenches were dug through the Holocene sediments into the Pleistocene subsoil. In general, the Holocene substrate of this region consists of a thick layer of peat (the top dates to the Middle Ages), covered by different layers of sandy and clayey sediments from the Zuiderzee phase (Late Middle Ages to c. AD 1942; Wiggers, 1955).

Studying the sections of the eight test trenches clearly revealed the nature of the linear structures: they represent a network of ditches that were dug into the peat before the area was overtaken by the Zuiderzee. The linear structures, slightly higher than their surroundings, represent the lowest parts of the organic clayey sediments deposited in the ditches before the major marine erosion of the Zuiderzee started (Figure 9). During the Zuiderzee phase, major parts of the peatlands in the study area were flooded and/or washed away. The natural stratigraphy in the excavation area shows that the lower parts of the peatlands have survived, i.e. the Zuiderzee has only washed away the top of the peat layer. It also means that the exact dimensions of the ditches could not be documented as only the deepest parts were preserved. After the Zuiderzee had taken hold of the area, marine sediments were deposited on top of the remaining peat and the clayey fill (fresh water deposits) of the ditches. After the reclamation of the northeastern Zuiderzee, a continuous process of dehydration and oxidation of the former seabed started. It caused soil compaction, especially for the layers of peat that remained after the marine phase in the region. The weight of the clayey fill of the ditches had already compacted the underlying peat before and during the Zuiderzee phase, creating a clear contrast between the ditches (limited compaction) and their surroundings (more substantial compaction). As a result, an inversion of relief occurred: the ditches became visible on LiDAR as small elevations in the landscape.

Several large ditches can be distinguished from the other ditches, based on their greater width $(5-6 \mathrm{~m})$ and northwest-southeast-orientation. Interestingly, these larger ditches have the same 


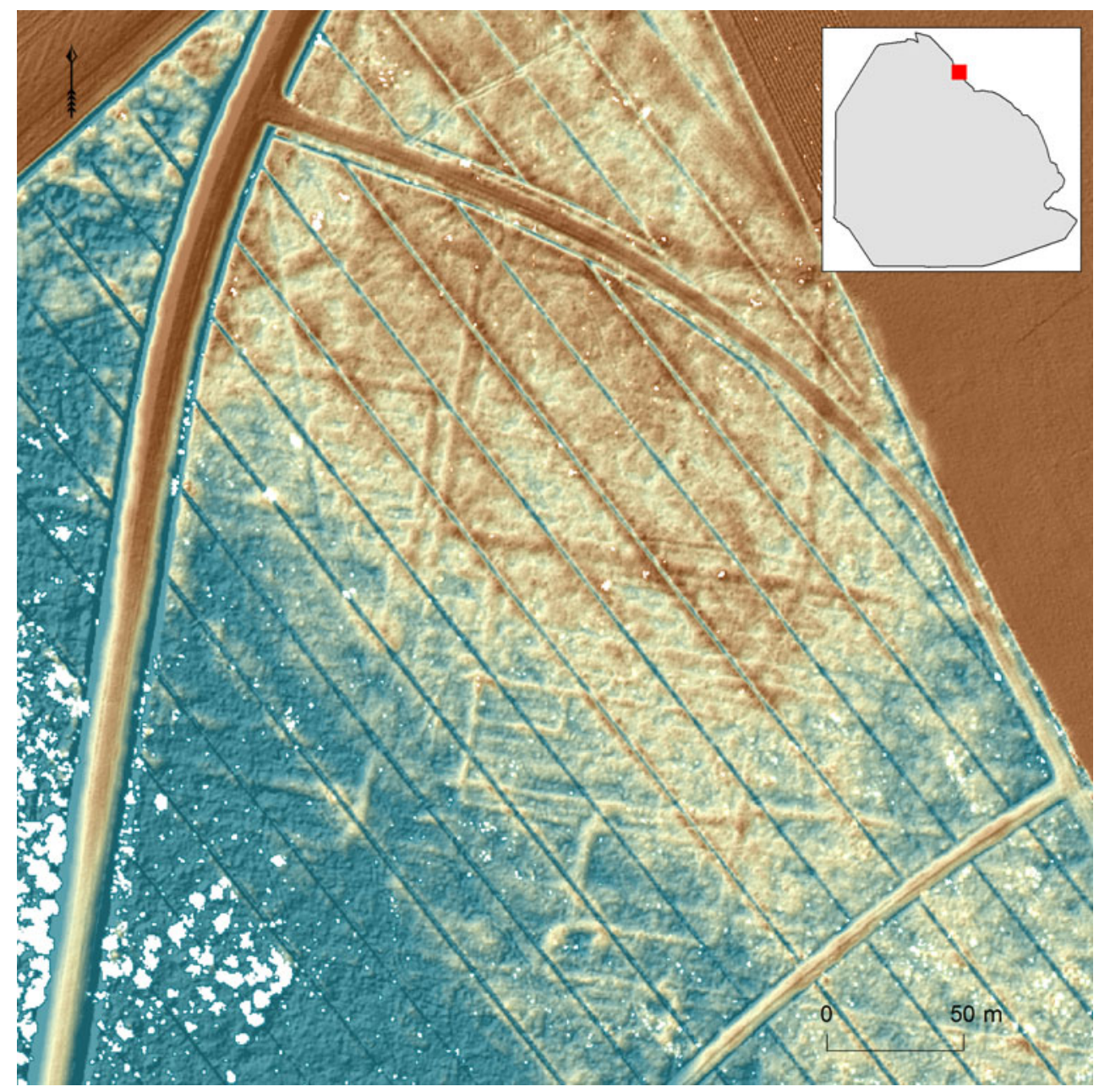

Figure 8. A dense network of linear structures is visible on the LiDAR data of the Kuinder Forest surface. The northwest-southeast oriented blue lines are modern drainage ditches (blue is low, red is high).

orientation as the old network of inland ditches visible on historical maps and LiDAR data (Figure 10). It suggests that the ditches in the excavation area were part of a larger system of field boundaries that served to drain the peatlands on which Fenehuysen II was built. Although no intact remains of the settlement have yet been found, several rectangular areas (measuring c. $30 \times 15 \mathrm{~m}$ ) were surrounded by small ditches. There is a good chance that these represent small medieval farmsteads with space for a single house or barn. The clayey substrate of numerous ditches contained large amounts of archaeological material, consisting of yellow and red bricks, pottery and stoneware sherds, animal bones with butchery marks, burnt daub, peat bricks, and rye pollen (Figure 11). The presence of the latter indicates that rye, one of the most frequently grown medieval cereals in the Netherlands, was also grown on the peaty soils near Fenehuysen II (Van Geel et al., 1983; Behre, 1992; Ettema, 2005). The assemblage clearly represents settlement 

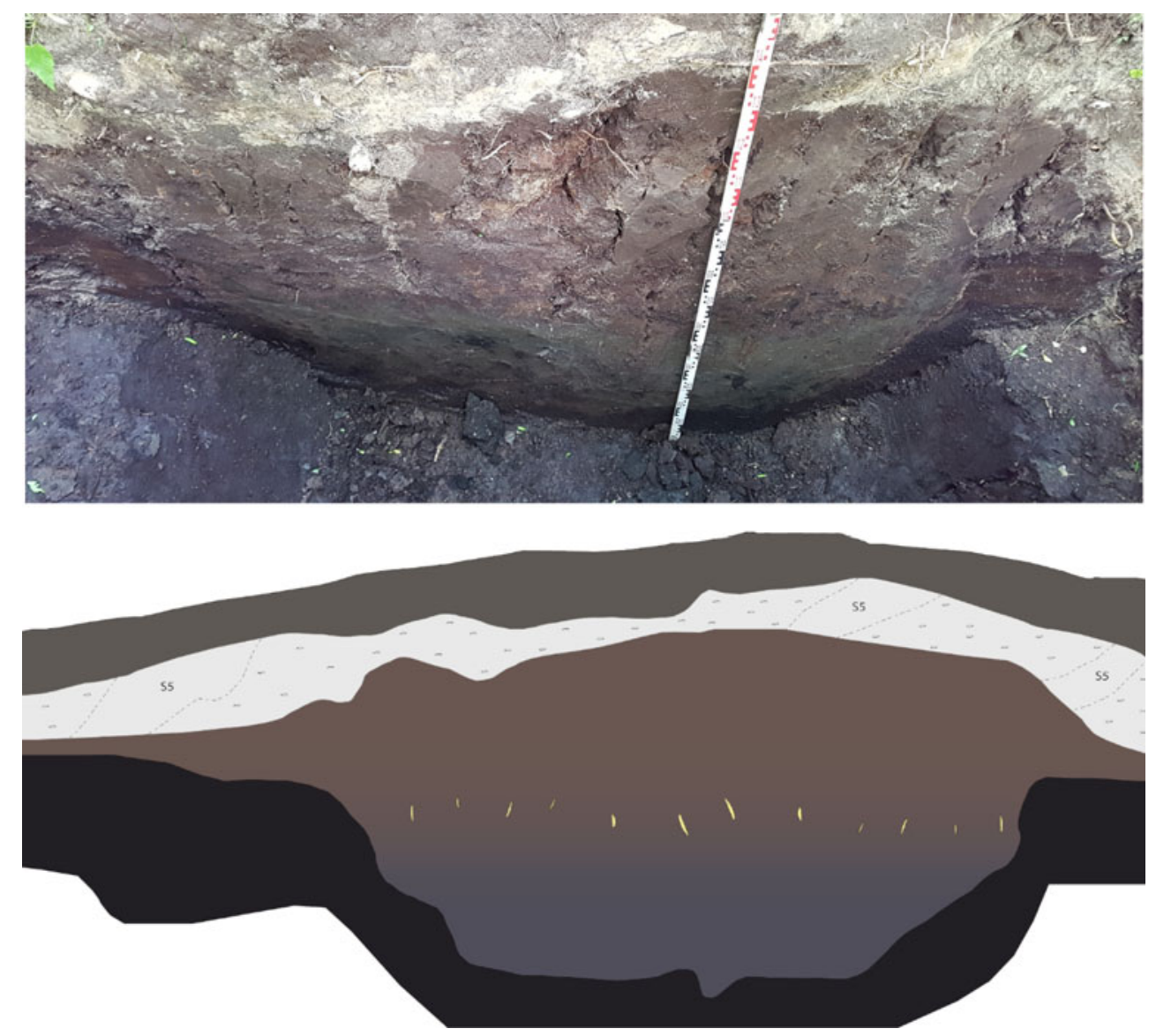

Figure 9. Photograph and drawing of a section of one of the test trenches dug through a historical ditch in the Kuinder forest.

noise as described in the methods section above. It is assumed that the objects were either deposited in the ditches on purpose (waste) or deposited in the ditches by the eroding force of storm floods. As the test trenches only targeted the ditches, no information is available for the small areas enclosed by the ditches. Several other ditches with almost no archaeological objects must represent ditches that were further away from the farmsteads. Clearly, more archaeological research is required to find out whether in situ remains, presumably belonging to Fenehuysen II, are still present. As the top of the peat was washed away by the Zuiderzee, it is unlikely that the foundations of houses survive in situ. Only the deepest parts of features like wells and pits might still be present. Past and present archaeological research has shown that in some parts of the north-eastern Zuiderzee region people lived on small artificial mounds (Schokland island) and protected themselves against the water by constructing dikes. It remains unclear whether this also goes for Fenehuysen II: some dike remains (discolorations on aerial photographs) have been found to the north-west of the former settlement, but there is no evidence that proves the presence of mound remains (see Van Popta, 2017).

The main category of archaeological objects consists of pottery sherds and 


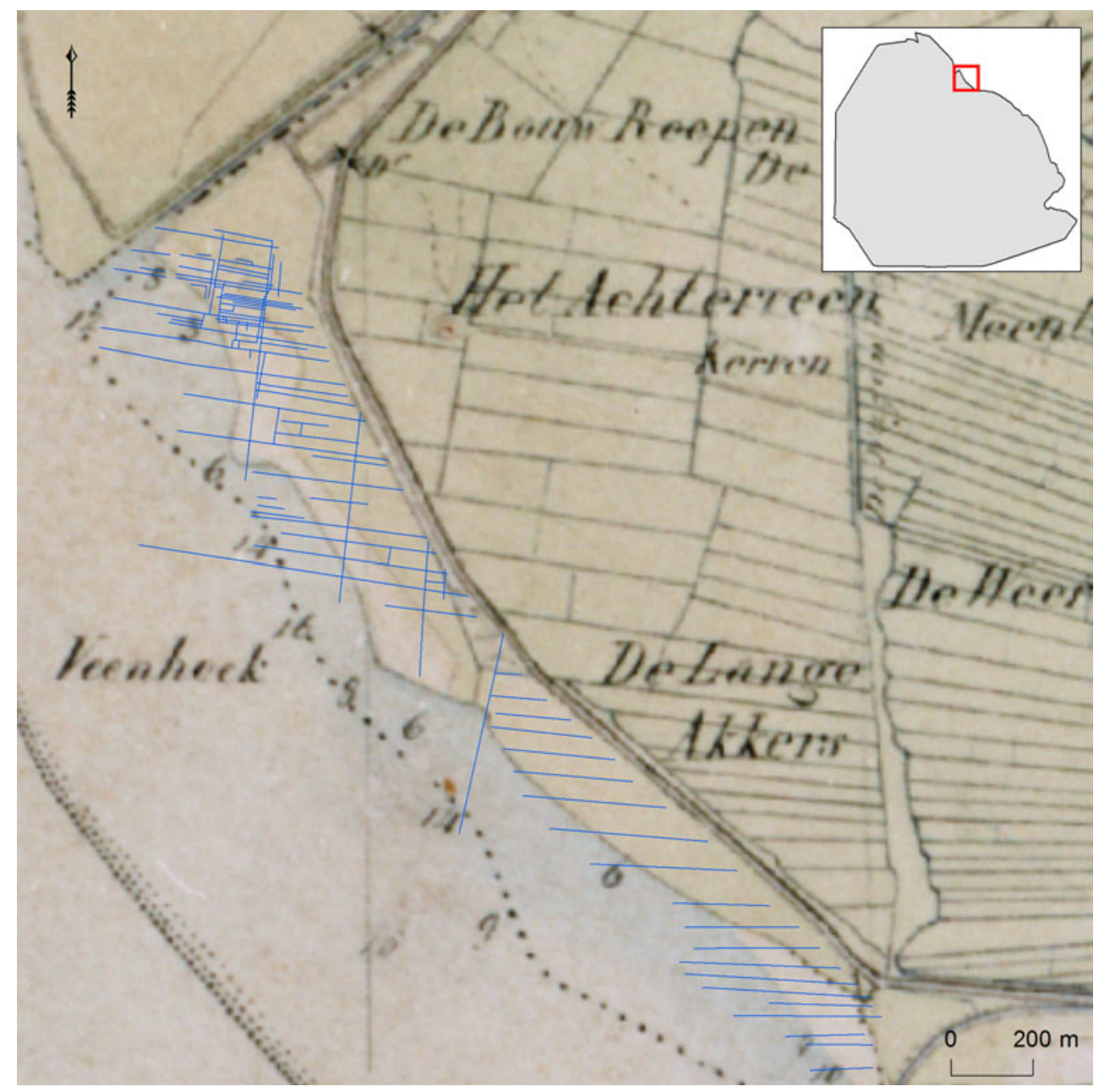

Figure 10. Overview of the boundary system in the Kuinder forest (blue lines) and the historical inland field system depicted on the 1850 Topographical Military Map.

bricks. The earliest sherds (Globular pottery, Paffrath pottery) date to the Late Middle Ages, while the latest sherds date to the seventeenth century (redware, early stoneware). No intact object was found, but many sherds belong to jars and plates. The bricks are either yellow or red and some have a rounded surface owed to water erosion. These bricks, together with fragments of burnt daub, are likely to represent the remains of buildings in Fenehuysen II. The ditches also contained a relatively large number of animal bones. Many bones, mainly belonging to cattle of different ages, had clear butchery marks, indicating that they are consumption waste. Altogether, the assemblage in the ditches represents the leftovers of a settlement that was threatened by marine erosion. As only small parts of the ditches have been examined, many more objects remain in the clayey fill of the ditches.

\section{A shifting settlement}

The history of the submerged settlement Fenehuysen highlights the dynamic nature 

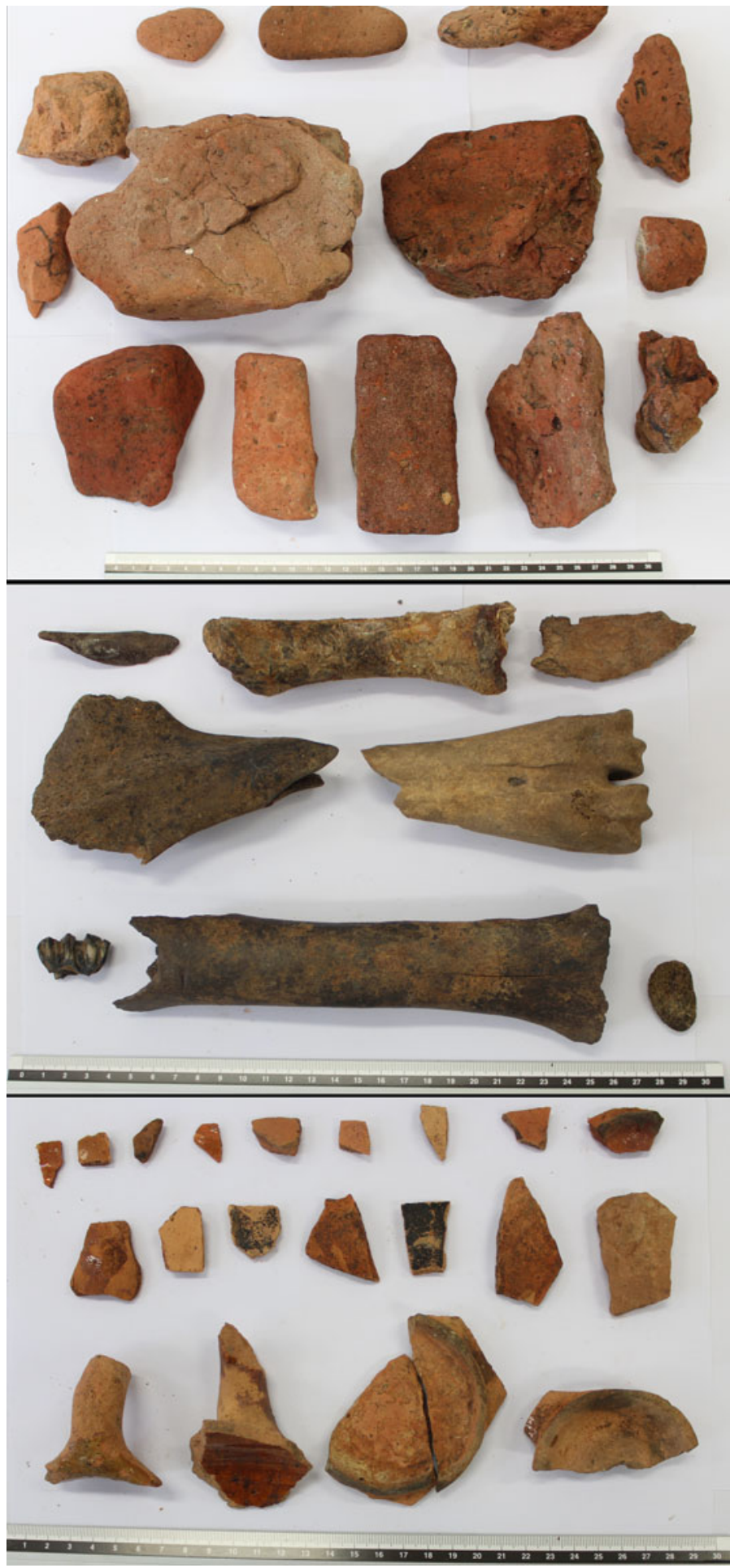

Figure 11. A selection of archaeological finds from the clayey fill of the late medieval ditches. From top to bottom: bricks, animal bones, red ware. 
of the north-eastern Zuiderzee region and the erosive force of the Zuiderzee. Historical maps confirm that the coastal settlement, referred to here as Fenehuysen II, lies along the former Zuiderzee coast, northwest of Kuinre. Archaeological investigations have shown that the remains of this settlement can be found in the Kuinder forest, corresponding to settlement area 5 (Figure 6). Fenehuysen I was, according to a seventeenth-century map, located to the south of Kuinre and corresponds to archaeological settlement area 4. Fenehuysen I was inhabited until the fourteenth century, as indicated by the dates of pottery sherds from that site. Fenehuysen II is estimated to have been inhabited between AD 1300 and 1700, also based on the dates of pottery sherds and stoneware fragments. Combining these archaeological and historical results leads to the following reconstruction (Figure 12): the first site of Fenehuysen was left to the mercy of the waves in the fourteenth century. There might even be a specific event responsible for the destruction of Fenehuysen I: on 10 October 1375, a massive storm hit the coasts of the North Sea, Wadden Sea, and Zuiderzee (Buisman, 1996). As a consequence, the inhabitants moved further north (inland) and founded Fenehuysen II. Both settlements must have had a small church or chapel, as mentioned in the historical charters and maps. The bricks found at the site of Fenehuysen II could have belonged to such a structure.

The second settlement was abandoned in the seventeenth century and the inhabitants of Fenehuysen II started living behind the dikes at Fenehuysen III. This is illustrated on eighteenth- and nineteenth-century maps. During this period, the word Fenehuysen was still used as a place-name, but its appearance must have been that of a hamlet: a couple of farms spread in the landscape. Historical archives mention the existence of five farms in 1763 and one remaining farm in 1793 (Kamman, 1985: 80). The topographical maps of 1850 and thereafter no longer mention the name Fenehuysen, although the descriptions Acbterveen (behind peat) and Veenhoek (peat corner) have been used in the vicinity of Fenehuysen III (for toponyms, see the Topographical Military Map of 1850 and the Bonnebladen maps of the nineteenth-twentieth century). Now, all that remains of Fenehuysen III is a small circular elevation in the fields, also visible on nineteenth-century maps. This site has not yet been archaeologically examined, although local people claim to have found sherds and bricks on the surface. Archaeological investigations on this site may indeed reveal the final remains of Fenehuysen.

The shifting nature of Fenehuysen is but one example of late medieval shifting settlements. There are more settlements in the Netherlands, such as Rouveen, Staphorst, Elburg and even the nearby castle of Kuinre, which experienced a similar shift for several reasons (search for dry land or fertile grounds; see Bos, 1988; Spek et al., 1996; De Boer \& Geurts, 2002). The same goes for the reclaimed lands of the Noordoostpolder, in which the remains of submerged settlements were found; there are more examples of reclaimed lands in the Netherlands (e.g. the Beemster, Scheemer, and Purmer polders) and elsewhere (e.g. De Polders in Belgium and Nordstrand in Germany). In addition, remains of medieval and early modern submerged settlements can be found in other parts of the Netherlands, like northern Frisia and Groningen (many artificial settlement mounds), Zeeland (Verdronken land van Saefthinge and Reimerswaal), and further afield (e.g. Jomsborg and Vineta). However, the Noordoostpolder should be considered a unique landscape due to the combination of aspects presented here. 


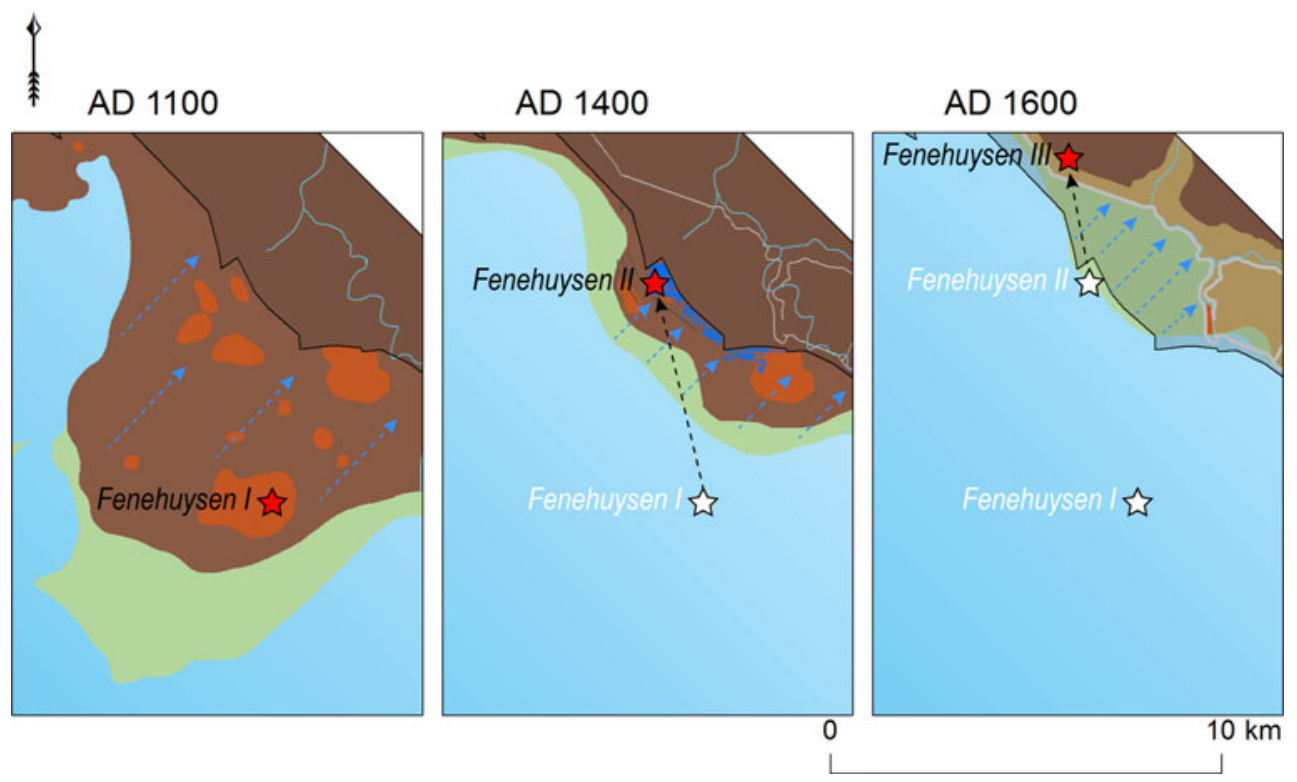

Figure 12. Reconstruction of the shifting nature of Fenehuysen. Brown: peatland; green: drowned peatland; orange: settlement remains: blue: water; grey: dikes.

\section{Conclusion}

The discovery of the late medieval network of ditches that contained the settlement remains of Fenehuysen II demonstrates that an interdisciplinary and methodological approach within the maritime cultural landscape concept can be rewarding. This maritime cultural landscape consists of many invisible physical remains like buried archaeological objects and a large number of immaterial aspects including place names, information on historical records and charters, palaeo-geographic interpretations and individual perception based on a specific perspective. Instead of merely focusing on archaeological data, an analysis of multiple kinds of data proved valuable.

The aim of this paper has been to recognize and characterize the submerged and eroded cultural remains in the Noordoostpolder region. Multiple criteria for identifying submerged settlements among the large number of archaeological objects from the region were defined and tested by searching for the submerged historic settlement of Fenehuysen. Although the datasets consulted are of a different nature, the innovative use of spatial and predictive analysis by GIS proved effective in the interpretation of the anthropogenic traces discovered in the Kuinder forest.

These traces, forming small rectangular entities, are interpreted as a late medieval network of ditches that contained relatively numerous archaeological objects, clearly representing settlement noise. They belong to the second settlement of Fenehuysen that existed roughly between $\mathrm{AD} 1300$ and 1700 . The first settlement, discovered further south, was in existence until the fourteenth century. Fenehuysen was built for a third time to the north-west of the second settlement and was almost completely abandoned by the end of the eighteenth century.

The settlement of Fenehuysen II needs to be explored further. Excavating the rectangular potential farmsteads in the Kuinder forest may show whether settlement remains like wells, pits, and 
foundations have survived in situ. There are also other settlements mentioned in historical charters like Marcnesse and Nagele that drowned in the north-eastern Zuiderzee region (Mol, 2011; Van Popta et al., in prep.). Finding them may be even harder as much of the area is heavily eroded and disturbed. Remote sensing and archaeological research might not be sufficient, but historical records and maps, when thoroughly examined, can help pinpoint the locations of settlements and provide further information on their existence.

To conclude: the existence of the Zuiderzee has influenced the life of people who inhabited the peatlands on which Fenehuysen was founded. Storm surges and tidal activity constantly threatened the small and vulnerable settlements, leaving their inhabitants no other option than to move further inland. This study illustrates the force of the Zuiderzee and its influence on the late medieval lands: clearly 'no country for men' (to borrow from the book and film title).

\section{ACKNOWLEDGements}

This work was supported by the Dutch Organization for Scientific Research (NWO; $\mathrm{PhDs}$ in Humanities, file no. 322-60-006) and is part of the author's doctoral research. I would like to thank Bas van Geel, Stijn Arnoldussen and an anonymous reviewer for their insightful comments. I am also grateful to Robert McKenzie, Sander Tiebackx, and Harold Broekmans for their support. Finally, I would like to thank the students of the University of Groningen who participated in the Kuinderbos excavation.

\section{REFERENCES}

Bartels, M. 2011. Steden in scherven. Vondsten uit beerputten in Deventer, Dordrecht,
Nijmegen en Tiel (1250-1900). Zwolle: Spa Uitgevers B.V.

Behre, K-E., 1992. The History of Rye Cultivation in Europe. Vegetation History and Archaeobotany, 1: 141-56.

Bos, J.M. 1988. Landinrichting en archeologie: het bodemarchief van Waterland (NAR 6). Amersfoort: Rijksdienst voor het Oudheidkundig Bodemonderzoek.

Buisman, J. 1996. Duizend jaar weer, wind en water in de Lage landen 2. 1300-1450. Franeker: Uitgeverij Van Wijnen.

Davis, O. 2008. Processing and Working with LiDAR Data in ArcGIS: A Practical Guide for Archaeologists. Aberystwyth: Royal Commission on the Ancient and Historical Monuments of Wales.

De Boer, P.C. \& Geurts, A.J. 2002. Oude burchten in het nieuwe land. De middeleeuwse kastelen van Kuinre in de Noordoostpolder. Lelystad: Stichting Uitgeverij de Twaalfde Provincie.

De Bont, C. 2008. Vergeten land. Ontginning, bewoning en waterbeheer in de westnederlandse veengebieden (800-1350). PhD dissertation, Wageningen University.

Duncan, B.G. 2006. The Maritime Archaeology and Maritime Cultural Landscapes of Queenscliffe: A Nineteenth Century Australian Coastal Community. Unpublished $\mathrm{PhD}$ dissertation, James Cook University, Queensland, Australia.

Ettema, W. 2005. Boeren op het Veen. Een ecologisch-historische benadering (10001500). Holland, 1: 239-58.

Geurts, A.J. 2005. Urk. De geschiedenis van een eiland. Lelystad: Nieuw Land Erfgoedcentrum.

Ingold, T. 1993. The Temporality of Landscape. World Archaeology, 25: 152-74.

Kamman, R. 1985. Geschiedenis van Kuinre en omgeving. Hoogersmilde: Grafiplan.

Ministerie van Verkeer en Waterstaat. 19201976. Driemaandelijks bericht betreffende de Zuiderzeewerken. Den Haag: Ministerie van Verkeer en Waterstaat.

Mol, J.A. 2011. De middeleeuwse veenontginningen in Noordwest-Overijssel en ZuidFriesland: datering en fasering. Jaarboek voor Middeleeuwse Geschiedenis, 14: 46-90.

Mol, J.A. \& Van Vliet, K. 1998. De oudste oorkonden van het Sint-Odulfusklooster van Staveren. Jaarboek voor Middeleeurwse Geschiedenis, 1: 73-134.

Pierik, H.J., Cohen, K.M., Vos, P.C., Van der Spek, A.J.F. \& Stouthamer, E. 2016. Late 
Holocene Coastal-plain Evolution of the Netherlands: The Role of Natural Preconditions in Human-induced Sea Ingressions. Proceedings of the Geologists' Association, 128: 180-97.

Spek, M., Zeiler, F.D. \& Raap, E. 1996. Van de Hunnepe tot de zee; de geschiedenis van het Waterschap Salland. Kampen: IJsselacademie.

Van den Biggelaar, D.F.A.M., Kluiving, S.J., Van Balen, R.T., Kasse, C., Troelstra, S. R. \& Prins, M.A. 2014. Storms in a Lagoon: Flooding History during the Last 1200 Years Derived from Geological and Historical Archives of Schokland (Noordoostpolder, The Netherlands). Netherlands Journal of Geosciences, 93: 17596.

Van Geel, B., Hallewas, D.P. \& J.P. Pals 1983. A Late Holocene Deposit under the Westfriese Zeedijk near Enkhuizen (Prov. of Noord-Holland, the Netherlands): Palaeoecological and Archaeological Aspects. Review of Palaeobotany and Palynology, 39: 269-335.

Van Hezel, G. \& Pol, A. 2008. Schokland en omgeving. Leven met water. Utrecht: Matrijs.

Van Holk, A.F.L. 2017. The Zuiderzee (the Netherlands). Highway, Fishing Ground and Power Landscape. In: J. Gawronski, A.F.L. van Holk \& J. Schokkenbroek, eds. Ships and Maritime Landscapes. Proceedings of the Thirteenth International Symposium on Boat and Ship Archaeology, Amsterdam 2012. Eelde: Barkhuis, pp. 7378.

Van Popta, Y.T. 2016. Taken by the Sea. New Analyses on the Dynamic Past of the Maritime Cultural Landscape Known as the Former Zuiderzee (the Netherlands). Cambridge Archaeological Review, 31: 75-90.

Van Popta, Y.T. 2017. Opgespoorde sporen van bewoning. Een archeologische, historische en geografische interpretatie van het laatmiddeleeuwse landschap van de Noordoostpolder. Tijdschrift voor Historische Geografie, 2: 130-43.

Van Popta, Y.T. \& Aalbersberg, G. 2016. Onbekend maar niet onbemind: terpen en terponderzoek in de Noordoostpolder. In: A. Nieuwhof, ed. Van Wierhuizen tot Achlum. Honderd jaar archeologisch onderzoek in terpen en wierden. Groningen: Vereniging voor Terpenonderzoek, pp. 129-40.
Van Popta, Y.T., Westerdahl, C.L. \& Duncan, B.G. 2019. Maritime Culture in the Netherlands: Accessing the Late Medieval Maritime Cultural Landscapes of the North-Eastern Zuiderzee. International Journal of Nautical Archaeology, 48: 172-88. https://doi.org/ 10.1111/1095-9270.12333.

Van Popta, Y.T., Cohen, K.M., Vos, P.C. \& Spek, M. in prep. Reconstructing Eroded Medieval Landscapes: An Interdisciplinary Palaeogeographical Approach to the Maritime Cultural Landscape of the Noordoostpolder (Zuyder Zee area, The Netherlands) between A.D. 1100 and 1400. Journal of Landscape History.

Van Zijverden, W.K. 2017. After the Deluge. A Palaeogeographical Reconstruction of Bronze Age West-Frisia (2000-800 bc). PhD dissertation, Leiden University.

Vos, P.C. 2015. Origin of the Dutch Coastal Landscape. Long-term Landscape Evolution of the Netherlands during the Holocene Described and Visualized in National, Regional and Local Palaeogeographical Map Series. $\mathrm{PhD}$ dissertation, Utrecht University.

Westerdahl, C.L. 1978. Marinarkeologisk inventering med utgångspunkt frän ett norrlåndskt exempel. C-uppsats, Arkeologi. Unpublished $\mathrm{PhD}$ dissertation, University of Stockholm.

Westerdahl, C.L. 1992. The Maritime Cultural Landscape. The International Journal of Nautical Archaeology, 21: 5-14.

Westerdahl, C.L. 2004. Maritime Cultures and Ship Types: Brief Comments on the Significance of Maritime Archaeology. The International Journal of Nautical Archaeology, 23: 265-70.

Westerdahl, C.L. 2008. Fish and Ships. Towards a Theory of Maritime Culture. Deutsches Schiffahrtsarchiv, Wissenschaftliches Jabrbuch des Deutschen Schiffahrtsmuseums, 30: 191-236.

Westerdahl, C.L. 2011. The Maritime Cultural Landscape Revisited. In: B. Ford, ed. The Archaeology of Maritime Landscapes. New York: Springer, pp. 33144.

Westerdahl, C.L. 2013. The Maritime Cultural Landscape. In: A. Catsambis, B. Ford \& D.L. Hamilton, eds. The Oxford Handbook of Maritime Archaeology. Oxford: Oxford University Press, pp. 733-62. 
Wiggers, A.J. 1955. De wording van het Noordoostpoldergebied. Een onderzoek naar de physisch-geografische ontwikkeling van een sedimentair gebied. Zwolle: Tjeenk Willink.

\section{Biographical Notes}

Yftinus van Popta is a $\mathrm{PhD}$ student in maritime archaeology at the University of Groningen. After specializing in maritime archaeology during his Master's degree, he started his NWO-funded $\mathrm{PhD}$ research on the late medieval maritime cultural landscape of the Zuiderzee region in the Netherlands, combining data from archaeological, geological, historical, and geographical sources in a spatial environment.

Address: Institute of Archaeology, University of Groningen, Poststraat 6, 9712 ER Groningen, The Netherlands. [email: y.t.van.popta@rug.nl]

\section{Pas un pays pour des hommes : à la recherche des habitats submergés de la fin du Moyen Age dans le nord-est du Zuiderzee au Pays-Bas}

Cet article traite du paysage culturel maritime autrefois recouvert par le Zuiderzee (1170-1932 apr. J.-C.) au centre des Pays-Bas. Depuis l'assèchement à grande échelle des terres gagnées sur la mer (1932-1968), de nombreux vestiges ont révélé une culture maritime submergée et érodée sous forme d'îles disparues, d'habitats submergés, d'anciens terroirs, d'épaves et de réseaux socio-économiques évanouis. Le secteur nord-est de cette région en particulier, connu sous le nom de Noordoostpolder, témoigne des luttes que les Néerlandais ont mené contre la mer. L'examen des données physiques et autres provenant de cette région permet de donner une idée de cet espace culturel maritime à la fin du Moyen Age en comparant la répartition et de la densité des vestiges aux données livrées par les documents historiques et aux résultats de la télédétection. Cette approche interdisciplinaire a mené à la découverte d'un habitat submergé à Fenehuysen. Translation by Madeleine Hummler

Mots-clés: habitats submergés, fin du Moyen Age, Zuiderzee, paysage culturel maritime, Fenehuysen, Pays-Bas

\section{Kein Land für Menschen: auf der Spur von spätmittelalterlichen überschwemmten Siedlungen in der nordöstlichen Zuiderzee Gegend in den Niederlanden}

Dieser Artikel betrifft die maritime Kulturlandschaft der ehemaligen Zuiderzee (ca. 1170-1932 n. Chr.) in der Mitte der heutigen Niederlande. Seit der umfangreichen Landgewinnung vom Meer (1932-1968) sind zahlreiche Überreste zutage gekommen; diese Spuren lassen eine überschwemmte und erodierte spätmittelalterliche Kulturlandschaft erkennen, in der Form von verschwundenen Inseln, überschwemmte Siedlungen, ehemaliger Ackerbau, Schiffbrüche, also sozioökonomische Netzwerke. Besonders im nordöstlichen Teil dieser Gegend, heute als Noordoostpolder bekannt, gibt es Belege der dynamischen Kämpfe der Niederländer gegen die Macht des Meeres. Die Untersuchung der materiellen und immateriellen Daten aus der Gegend gibt uns einen Einblick in diese spätmittelalterliche maritime Kulturlandschaft. Die Untersuchung der Verbreitung und Dichte der spätmittelalterlichen Funde und der Vergleich dieser Streunng mit historischen Quellen und mit Fernerkundungsergebnissen haben dazu geführt, die Spuren einer überschwemmten Siedlung in Fenehuysen zu entdecken. Translation by Madeleine Hummler

Stichworte: überschwemmte Siedlungen, Spätmittelalter Ages, Zuiderzee, maritime Kulturlandschaft, Fenehuysen, Niederlande 